\title{
The effect of adding antimicrobial peptides to milk inoculated with Staphylococcus aureus and processed by high-intensity pulsed-electric field
}

\author{
A. Sobrino-Lopez, * P. Viedma-Martínez, † H. Abriouel,† E. Valdivia,ł A. Gálvez,† and O. Martin-Belloso*1 \\ *Department of Food Technology, University of Lleida, Avda. Alcalde Rovira Roure 191, 25198 Lleida, Spain \\ †Microbiology Division, Health Sciences Department, University of Jaen, Campus Las Lagunillas s/n, 23071 Jaen, Spain \\ ‡Department of Microbiology, University of Granada, 18071 Granada, Spain
}

\begin{abstract}
The use of high-intensity pulsed-electric field (HIPEF) and antimicrobial substances of natural origin, such as enterocin AS-48 (AS-48), nisin, and lysozyme, are among the most important nonthermal preservation methods. Thus, the purpose of this study was to evaluate the combined effect on milk inoculated with Staphylococcus aureus of the addition of AS- 48 with nisin or lysozyme, or both, together with the use of HIPEF. Synergy was observed in the reduction of Staph. aureus counts with the following combination methods: i) addition of AS-48 and nisin, ii) addition of AS-48 plus use of HIPEF, and iii) addition of AS-48 and nisin plus use of HIPEF. Specifically, when 28 arbitrary units/ $\mathrm{mL}$ of AS-48 and $20 \mathrm{IU} / \mathrm{mL}$ of nisin were added to the milk, and it was treated with HIPEF for $800 \mu \mathrm{s}$, over $6 \mathrm{log}$ reductions were observed in the microorganism. In general, Staph. aureus inactivation was dependent on HIPEF treatment time, antimicrobial doses, and medium $\mathrm{pH}$. During storage of the treated milk, survivor population was related to peptide concentration and temperature. Final cell viability was influenced by the sequence in which the treatments were applied: the addition of AS-48 or AS-48 and nisin was more effective before than after HIPEF treatment. The results obtained indicate that the combination of HIPEF and antimicrobials could be of great interest to the dairy industry, although it is necessary to study further the way in which the combined treatments act.
\end{abstract}

Key words: milk, high-intensity pulsed-electric field, enterocin AS-48, nisin

\section{INTRODUCTION}

The interest of the food industry in food preservation through nonthermal methods arises, in general, from

Received December 23, 2008

Accepted January 16, 2009.

${ }^{1}$ Corresponding author: omartin@tecal.udl.es the fact that they make it possible to guarantee the microbiological qualities of a product while, at the same time, minimizing the effect on its sensory properties. Of these methods, the use of high-intensity pulsed-electric field (HIPEF) and of antimicrobial compounds of natural origin are of special interest because of their great potential as preservation treatments in a wide range of food.

High-intensity pulsed-electric field is one of the most important nonthermal techniques for treating liquid foods for 2 reasons: first, because it is possible to use it industrially on continuous-flow processing lines, specifically before reaching the aseptic packaging equipment, and, second, because of its wide spectrum of microorganism inactivation. However, the resistance of different microorganisms to HIPEF treatment is dependent on many factors, such as food media (Bendicho et al., 2002), electrical variables (Sobrino-López et al., 2006) and type of microorganism, species, and even strains (MacGregor et al., 2000). On the basis of a hurdle approach, the combination of HIPEF with other preservation methods can improve the final effectiveness of the treatment. Thus, it has been observed that the simultaneous combination of HIPEF with certain added antimicrobial substances results in a synergistic effect in the cell death (Wu et al., 2005; Sobrino-López and Martín-Belloso, 2006).

Among antimicrobial compounds of natural origin, we should differentiate between those that form part of the intrinsic composition of the food, such as enzymes capable of cell-membrane damages, and those that are formed during its processing, such as antimicrobial substances of bacterial origin released during fermentation of the product. Lysozyme is a component usually present in milk whose muramidase activity focuses above all on gram-positive microorganisms, although certain gram-negative bacteria have also been identified as being sensitive to this substance (Masschalck and Michiels, 2003). As a preservative agent, lysozyme is generally recognized as safe by the Joint Food and Agriculture Organization-World Health Organization 
(WHO Food Additives Series 30) and as quantum satis by European directive 95/2/EC on food additives other than colors and sweeteners.

With regard to the natural compounds added during the food processing, bacteriocins are substances with antimicrobial activity produced by bacteria (Gálvez et al., 2007). Especially important are those bacteriocins produced by acid-lactic bacteria because they are often related with a large number of fermentations in the food industry. In particular, nisin is a peptide produced by Lactococcus lactis ssp. lactis. Its lethal activity covers a wide spectrum of gram-positive pathogenic and food-spoilage bacteria (Rodríguez et al., 2000) and it can be used in a wide variety of foods, including dairy products (Jung et al., 1992). Because of its history as a preservative agent, nisin was accepted as a food additive, E-234, in the European Union (EEC, 1983) and, later, was qualified as generally recognized as safe by the FDA (1988).

In contrast to the long-use history of nisin, other bacteriocins have been identified and characterized only recently, although some authors have already pointed out the great potential of some of them to be used in the food industry. Enterocin AS-48 (AS-48) is a circular peptide, which is stable over a wide $\mathrm{pH}$ range, heatresistant, and displays a broad antimicrobial spectrum. It is produced by Enterococcus faecalis (Gálvez et al., 1986) and shows feasibly applications in food such as sausages (Ananou et al., 2005b), vegetable sauces (Molinos et al., 2005), fruit juices (Grande et al., 2005), and dairy products (Muñoz et al., 2007). However, there is still little or no information on the effectiveness of this bacteriocin and its degree of microorganism inactivation when combined with HIPEF, or even with other bacteriocins. Because Staphylococcus aureus is an important milk- and dairy product-related pathogen, the purpose of this study was to evaluate the effect of enterocin AS-48 added alone to milk inoculated with Staph. aureus or in combination with nisin or lysozyme, and processed simultaneously with HIPEF treatment. The influence of processing parameters, the storage conditions of the samples treated, and the sequence of application of each treatment were also studied.

\section{MATERIALS AND METHODS}

\section{Staphylococcus aureus Culture}

Staphylococcus aureus CECT 240 (Food Technology Department, University of Lleida, Spain) was the target microorganism. The strain was maintained routinely on slants of plate count agar (Biokar Diagnostics, Beauvais, France) at $4^{\circ} \mathrm{C}$ until it was used.
Strain growth was performed by incubating cultures on tryptone soy broth at $35^{\circ} \mathrm{C}$ for $6 \mathrm{~h}$. Inoculum concentration was determined by optical measurement. A population density of approximately $10^{8} \mathrm{cfu} / \mathrm{mL}$ matches an absorbance value between 0.6 and 0.7 at $620 \mathrm{~nm}$.

\section{Skim Milk}

Homogenized UHT skim milk was obtained from a dairy plant and stored at $4^{\circ} \mathrm{C}$ (Puleva, Mollerussa, Lleida, Spain). Natural pH of milk was $6.80 \pm 0.02$ measured by a pH meter (Crison 2001 pH-meter, Crison Instruments SA, Alella, Barcelona, Spain). The electrical conductivity of the skim milk was 5.55 $\pm 0.04 \mathrm{mS} / \mathrm{cm}$. The measurement was performed at $25^{\circ} \mathrm{C}$ and determined with a conductivity meter (Testo 240 conductivimeter; Testo GmBh \& Co, Lenzkirch, Germany).

\section{Preparation of Enterocin AS-48 Solution}

Enterococcus faecalis A-48-32 (Martínez-Bueno et al., 1990) was used as enterocin AS-48 producer. The bacteriocin solution was obtained by purification of cultured broths of the producer strain after concentration by cation-exchange chromatography in accordance with the method described by Abriouel et al. (2003). Bacteriocin concentrates were desalted through 2,000 Da cut-off dialysis tubing (Sigma-Aldrich, Steinheim, Germany), filtered through $0.22-\mu \mathrm{m}$ pore size low-protein binding filters (Millex GV, Millipore Corp., Belford, MA) under sterile conditions. The AS-48 activity was determined by the agar well diffusion method (Gálvez et al., 1986). The enterocin AS-48 preparation resulted in a concentration of 3,500 arbitrary units per $\mathrm{mL}$ $(\mathbf{A U} / \mathrm{mL})$, which was 10 -fold diluted with demineralized water to obtain the final solution.

\section{Sample Preparation}

Samples with Staph. aureus were prepared by inoculating the microorganism in skim milk to a final concentration of approximately $10^{7} \mathrm{cfu} / \mathrm{mL}$. According to the experimental design, $\mathrm{pH}$ of milk was adjusted by adding lactic acid (L(+)-lactic acid, Panreac, Barcelona, Spain). When acidity was adjusted to $5.0 \mathrm{pH}$, electrical conductivity of milk was $6.99 \pm 0.13 \mathrm{mS} / \mathrm{cm}$.

\section{HIPEF Equipment and Treatment}

A continuous-flow HIPEF system was used to carry out this study. The treatment device was an OSU-4F 
Table 1. Inactivation of Staphylococcus aureus in milk by combining added enterocin AS-48 and high-intensity pulsed-electric field (HIPEF)

\begin{tabular}{lccccc}
\hline $\begin{array}{l}\text { Assay } \\
\text { number }\end{array}$ & Point type & $\begin{array}{c}\text { Enterocin AS-48 } \\
\text { dose }(\mathrm{AU} / \mathrm{mL})\end{array}$ & $\begin{array}{c}\text { HIPEF treatment } \\
\operatorname{time}^{2}(\mu \mathrm{s})\end{array}$ & Milk pH & $\begin{array}{c}\text { Microbial inactivation } \\
\left(-\log s^{3}\right)\end{array}$ \\
\hline 1 & Factorial & 28.0 & 1,200 & 5.0 & 2.8 \\
2 & Factorial & 28.0 & 120 & 6.8 & 1.6 \\
3 & Factorial & 3.5 & 1,200 & 6.8 & 3.3 \\
4 & Factorial & 3.5 & 120 & 5.0 & 1.2 \\
5 & Axial & 3.5 & 660 & 5.9 & 3.1 \\
6 & Axial & 28.0 & 660 & 5.9 & 1.8 \\
7 & Axial & 15.8 & 120 & 5.9 & 3.3 \\
8 & Axial & 15.8 & 1,200 & 5.9 & 3.2 \\
9 & Axial & 15.8 & 660 & 5.0 & 3.8 \\
10 & Axial & 15.8 & 660 & 6.8 & 3.0 \\
11 & Center & 15.8 & 660 & 5.9 & 3.1 \\
12 & Center & 15.8 & 660 & 5.9 & 2.6 \\
13 & Center & 15.8 & 660 & 5.9 & 2.9 \\
14 & Center & 15.8 & 660 & 5.9 & \\
15 & 15.8 & 660 & 5.9 & \\
${ }^{1}$ Assay number does not correspond to the order of processing. & \\
${ }^{2} \mathrm{HIPEF}$ treatment was set at $35 \mathrm{kV} / \mathrm{cm}, 6 \mu$ s of pulse width, and $75 \mathrm{~Hz}$ of pulse frequency at bipolar mode. \\
${ }^{3}$-log $s=$ microbial inactivation as mean of 2 replicates.
\end{tabular}

HIPEF unit (Ohio State University, Columbus) that discharges square-shape pulses within 8 collinear chambers, in which gap distance was $0.29 \mathrm{~cm}$ and each treatment chamber volume was $0.012 \mathrm{~cm}^{3}$. Electrical parameters were set at $35 \mathrm{kV} / \mathrm{cm}$ of electric field strength, $6 \mu \mathrm{s}$ of pulse width, and $75 \mathrm{~Hz}$ of pulse frequency in bipolar mode in accordance with previous studies. Treatment temperature was kept under $25^{\circ} \mathrm{C}$ using a cooled water bath to rule out thermal effects. The antimicrobial action of HIPEF treatment against Staph. aureus was determined by treating samples at their natural $\mathrm{pH}$ and $\mathrm{pH} 5.0$ up to a final treatment time of $1,200 \mu \mathrm{s}$. Each trial was performed in triplicate.

\section{Enterocin AS-48 in Combination with Nisin or Lysozyme}

The single effect of enterocin AS-48, nisin (N 5764, $2.5 \%$ nisin, 1,000,000 IU/mg, Sigma-Aldrich) and lysozyme (L 2879, 43,560 IU of lysozyme/mg of solid, Sigma-Aldrich) against Staph. aureus was measured by exposing samples at their natural $\mathrm{pH}$ and $\mathrm{pH} 5.0$ to a bacteriocin concentration up to $28 \mathrm{AU} / \mathrm{mL}, 20 \mathrm{IU} /$ $\mathrm{mL}$, and 5,000 IU/mL, respectively. The effectiveness of AS-48 was also evaluated when added together with nisin or lysozyme and holding samples for $1 \mathrm{~h}$ at room temperature. All assays were performed in triplicate.

\section{Application of HIPEF Treatment in Combination with Added Enterocin AS-48}

The susceptibility of Staph. aureus against the combination of added enterocin AS-48 and HIPEF was studied by adding the bacteriocin to milk samples and then applying the HIPEF treatment. A response surface methodology (RSM) was set to study the effect of the combined treatment (Table 1). Process variables were AS-48 concentration ( 3.5 to $28 \mathrm{AU} / \mathrm{mL}$ ), $\mathrm{pH}$ of milk (5.0 to 6.8 ), and HIPEF treatment time (120 to $1,200 \mu \mathrm{s})$.

\section{Application of HIPEF Treatment in Combination with Added Enterocin AS-48 and Nisin or Lysozyme}

Resistance of Staph. aureus to the addition of AS-48 together with nisin before carrying out HIPEF treatment was also evaluated by a RSM (Table 2). Levels of the process variables were 1 to $20 \mathrm{IU} / \mathrm{mL}$ of nisin and 120 to $1,200 \mu \mathrm{s}$ of HIPEF treatment time. Similarly, samples with added AS-48 and lysozyme were also treated by HIPEF and setting a RSM, in which lysozyme varied from 300 to $5,000 \mathrm{IU} / \mathrm{mL}$ and HIPEF treatment time from 120 to 1,200 $\mu \mathrm{s}$. Enterocin AS-48 concentration was kept constant at $28 \mathrm{AU} / \mathrm{mL}$ in both cases.

\section{Sequence of Application}

The sequence of application of each treatment was evaluated by comparing the final microbial inactivation of adding the antimicrobial compounds before applying HIPEF with that of applying HIPEF after. Therefore, a mixture of $28 \mathrm{AU} / \mathrm{mL}$ of AS- 48 and $20 \mathrm{IU} / \mathrm{mL}$ of nisin or $5,000 \mathrm{IU} / \mathrm{mL}$ of lysozyme was added to HIPEFtreated samples at natural $\mathrm{pH}$ of milk by setting 1,200 $\mu \mathrm{s}$ of HIPEF treatment time and prolonging exposure 
Table 2. Microbial death of Staphylococcus aureus suspended in milk with added $28 \mathrm{AU} / \mathrm{mL}$ of enterocin AS-48 and treated under different conditions of nisin dose and high-intensity pulsed-electric field (HIPEF) treatment time

\begin{tabular}{|c|c|c|c|c|}
\hline \multirow[b]{2}{*}{ Assay number ${ }^{1}$} & \multirow[b]{2}{*}{ Point type } & \multicolumn{2}{|c|}{ Independent variables } & \multirow[b]{2}{*}{$\begin{array}{c}\text { Microbial } \\
\text { inactivation } \\
\left(-\log s^{3}\right)\end{array}$} \\
\hline & & $\begin{array}{l}\text { Nisin dose } \\
(\mathrm{IU} / \mathrm{mL})\end{array}$ & $\begin{array}{l}\text { HIPEF } \\
\text { treatment } \\
\text { time }^{2}(\mu \mathrm{s})\end{array}$ & \\
\hline 1 & Factorial & 1.0 & 120 & 2.7 \\
\hline 2 & Factorial & 20.0 & 120 & 3.2 \\
\hline 3 & Factorial & 1.0 & 1,200 & 4.3 \\
\hline 4 & Factorial & 20.0 & 1,200 & 5.1 \\
\hline 5 & Axial & 1.0 & 660 & 5.4 \\
\hline 6 & Axial & 20.0 & 660 & 6.6 \\
\hline 7 & Axial & 10.5 & 120 & 2.7 \\
\hline 8 & Axial & 10.5 & 1,200 & 4.6 \\
\hline 9 & Center & 10.5 & 660 & 5.4 \\
\hline 10 & Center & 10.5 & 660 & 5.3 \\
\hline 11 & Center & 10.5 & 660 & 5.5 \\
\hline 12 & Center & 10.5 & 660 & 5.0 \\
\hline 13 & Center & 10.5 & 660 & 5.2 \\
\hline
\end{tabular}

${ }^{1}$ Assay number does not correspond to the order of processing.

${ }^{2} \mathrm{HIPEF}$ treatment was set at $35 \mathrm{kV} / \mathrm{cm}, 6 \mu$ s pulse width, and $75 \mathrm{~Hz}$ of pulse frequency at bipolar mode.

${ }^{3}-\log s=$ microbial inactivation as mean of 2 replicates.

to the antimicrobial mixture for $1 \mathrm{~h}$ at room temperature. Assays were performed in triplicate.

\section{Storage Conditions of Treated Samples}

Samples with single and combined additions of AS-48, nisin, and lysozyme or those treated with a combination of HIPEF and different mixtures of the antimicrobial compounds were stored at $4^{\circ} \mathrm{C}$ and $22^{\circ} \mathrm{C}$. Population of Staph. aureus in the stored samples was evaluated after 24 and $48 \mathrm{~h}$. Assays were performed in triplicate.

\section{RSM}

Response surface methodology was performed to study the simultaneous effect of HIPEF and added AS48 and nisin or lysozyme (Tables 1 and 2). In each experimental model, a central composite and faced centered design was selected (Myers and Montgomery, 2002). Assays were replicated twice and the experimental order randomized within each block. Each trial was performed in triplicate. The effect of $n$ independent variables was modeled by using a second-order polynomial equation:

$$
-\log s=\beta_{0}+\sum_{i=1}^{n} \beta_{i} X_{i}+\sum_{i=1}^{n} \beta_{i i} X_{i}^{2}+\sum_{i=1}^{n-1} \sum_{j=i+1}^{n} \beta_{i j} X_{i} X_{j}
$$

where $-\log s$ is the microbial inactivation of Staph. aureus, $\beta_{i}$ are the regression coefficients, and factor $X_{i}$ represents the encoded values of the variables. Regression coefficients were estimated by model reduction, as such omitting nonsignificant terms $(P>0.05)$ from ANOVA. A 95\% confidence interval was set for all procedures. Design Expert 6.0.1 software (Stat Ease Inc., Minneapolis, MN) was used in all RSM analyses and generated plots.

\section{Microbial Inactivation of Staphylococcus aureus}

The untreated and treated samples were serially diluted in peptone saline solution, plated on slants of plate count agar, and incubated for $48 \mathrm{~h}$ at $35^{\circ} \mathrm{C}$. The number of viable cells of Staph. aureus after applying a treatment was expressed as survival fraction, $s$, which was calculated as $N / N_{0}$, where $N_{0}$ was the initial count in samples before any of the treatments and $N$ was the count after each treatment. Microbial inactivation was calculated as $-\log s$.

\section{RESULTS}

\section{Effect of Adding AS-48, Nisin, or Lysozyme, or AS-48 with Lysozyme}

The addition of $28 \mathrm{AU} / \mathrm{mL}$ of $\mathrm{AS}-48,20 \mathrm{IU} / \mathrm{mL}$ of nisin, or $5,000 \mathrm{IU} / \mathrm{mL}$ of lysozyme alone, and the combination of enterocin AS-48 $(28 \mathrm{AU} / \mathrm{mL})$ with lysozyme $(5,000 \mathrm{IU} / \mathrm{mL})$ caused no variation in survival of Staph. aureus in milk at its natural $\mathrm{pH}$ and $\mathrm{pH} 5.0$ after $1 \mathrm{~h}$ of exposure at room temperature, nor after 24 and 48 $\mathrm{h}$ of storage at 4 and $22^{\circ} \mathrm{C}$. On the contrary, the Staph. 
Table 3. Fate of Staphylococcus aureus inoculated in milk treated by enterocin AS-48 (28 AU/mL) and nisin (20 IU/mL) addition and storage at different temperatures ${ }^{1}$

\begin{tabular}{|c|c|c|c|c|c|c|}
\hline \multirow{2}{*}{ Storage $(\mathrm{h})$} & \multicolumn{3}{|c|}{$4^{\circ} \mathrm{C}$} & \multicolumn{3}{|c|}{$22^{\circ} \mathrm{C}$} \\
\hline & Untreated & \multicolumn{2}{|c|}{ Treated } & Untreated & \multicolumn{2}{|c|}{ Treated } \\
\hline 0 & $6.9 \pm 0.3$ & $6.9 \pm 0.3$ & $6.9 \pm 0.3$ & $6.9 \pm 0.3$ & $6.9 \pm 0.3$ & $6.9 \pm 0.3$ \\
\hline 1 & $6.9 \pm 0.3$ & $6.3 \pm 0.3$ & $6.1 \pm 0.3$ & $7.0 \pm 0.3$ & $5.8 \pm 0.3$ & $5.1 \pm 0.3$ \\
\hline 24 & $6.8 \pm 0.2$ & $5.6 \pm 0.4$ & $3.8 \pm 0.2$ & $8.7 \pm 0.3$ & $4.6 \pm 0.2$ & $0.7 \pm 0.3$ \\
\hline
\end{tabular}

${ }^{1}$ Survivors as $\log N$. Mean \pm standard deviation.

aureus population fell when $28 \mathrm{AU} / \mathrm{mL}$ of $\mathrm{AS}-48$ was combined with $20 \mathrm{IU} / \mathrm{mL}$ of nisin, although the level of inactivation depended on exposure time, milk $\mathrm{pH}$, and temperature. Thus, after $1 \mathrm{~h}$ of exposure to the 2 bacteriocins, $\log$ reductions of 1.8 and 1.1 in Staph. aureus were observed at 6.8 and $5.0 \mathrm{pH}$, respectively (Table $3)$. During storage, the activity of the 2 bacteriocins, in general, led to an even greater reduction in Staph. aureus population, although the number of survivors was lower at $22^{\circ} \mathrm{C}$ or at natural milk $\mathrm{pH}$ than at $4^{\circ} \mathrm{C}$ or at $5.0 \mathrm{pH}$. Up to 6 log reductions of the microorganism were observed when the milk was kept at its natural $\mathrm{pH}$ with $28 \mathrm{AU} / \mathrm{mL}$ of AS-48 and $20 \mathrm{IU} / \mathrm{mL}$ of nisin for 24 $\mathrm{h}$ at $22^{\circ} \mathrm{C}$. However, this tendency was blocked when storage was lengthened to $48 \mathrm{~h}$. On the one hand, the recovery in Staph. aureus counts to the initial inoculated level at both of the $2 \mathrm{pHs}$ under study revealed the ending of the bactericide effect of the 2 antimicrobials, whereas on the other hand, when the temperature was kept at $4^{\circ} \mathrm{C}$, the reduction increased progressively up to practically 4 log cycles over the $48 \mathrm{~h}$.

\section{Effect of HIPEF in Combination with Enterocin AS-48}

To determine the greatest level of Staph. aureus inactivation by HIPEF, different samples were processed at natural milk $\mathrm{pH}$ and at $\mathrm{pH} 5.0$, with a field intensity of $35 \mathrm{kV} / \mathrm{cm}$, a frequency of $75 \mathrm{~Hz}$ in bipolar mode, and a treatment time of $1,200 \mu \mathrm{s}$. This treatment resulted in $\log$ reductions in counts of Staph. aureus of $3.5 \pm 0.3$, with no significant differences in the level of destruction between the $2 \mathrm{pH}$ levels studied.

The effect of the addition of enterocin AS-48 to milk before HIPEF treatment was studied in accordance with the proposed RSM. The inactivation achieved for each combination of variables is shown in Table 1 . The ANOVA revealed that the results fit a second-order model, with a coefficient of determination $\left(\mathrm{R}^{2}\right)$, of 0.94

Table 4. Analysis of variance and significant regression coefficients for the response surface model of microbial inactivation of Staphylococcus aureus in milk at different $\mathrm{pH}$ by combining enterocin AS-48 and high-intensity pulsed-electric field (HIPEF; $35 \mathrm{kV} / \mathrm{cm}, 6 \mu \mathrm{s}$ of pulse width, and $75 \mathrm{~Hz}$ of frequency at bipolar mode)

\begin{tabular}{llrcc}
\hline Source $^{1}$ & MS & F-value & Probability $>$ F & Regression coefficients $^{2}$ \\
\hline Model & 1.09 & 14.83 & $0.0010^{3}$ & $-21.1 \pm 8.6$ \\
Intercept & & & & $-0.0635 \pm 0.0195$ \\
$e$ & 0.62 & 8.44 & $0.0228^{3}$ & $-0.00266 \pm 0.00340$ \\
$t$ & 3.68 & 50.09 & $0.0002^{3}$ & $0.04 \pm 2.64$ \\
$p$ & 0.45 & 6.15 & $0.0422^{3}$ & $-00346 \pm 0.00117$ \\
$e^{2}$ & 0.71 & 9.59 & $0.0174^{3}$ & $-0.722 \pm 0.207$ \\
$t^{2}$ & 1.10 & 14.92 & $0.0062^{3}$ & \\
$p^{2}$ & 0.90 & 12.18 & $0.0101^{3}$ & \\
$t \times p$ & 0.45 & 6.10 & $0.0428^{3}$ & \\
Lack of fit & 0.12 & 3.20 & 0.1456 & \\
Pure error & 0.038 & & & \\
SD & 0.27 & & & \\
Mean & 2.72 & & & \\
CV & 9.97 & & & \\
$\mathrm{R}^{2}$ & 0.94 & & & \\
Adjusted $\mathrm{R}^{2}$ & 0.88 & & & \\
\hline
\end{tabular}

${ }^{1} e=$ enterocin AS-48 concentration $(\mathrm{AU} / \mathrm{mL}) ; t=\mathrm{HIPEF}$ treatment time $(\mu \mathrm{s}) ; p=$ milk $\mathrm{pH}$

${ }^{2}$ Mean \pm standard deviation.

${ }^{3}$ Significant at $95 \%$ confidence interval. 

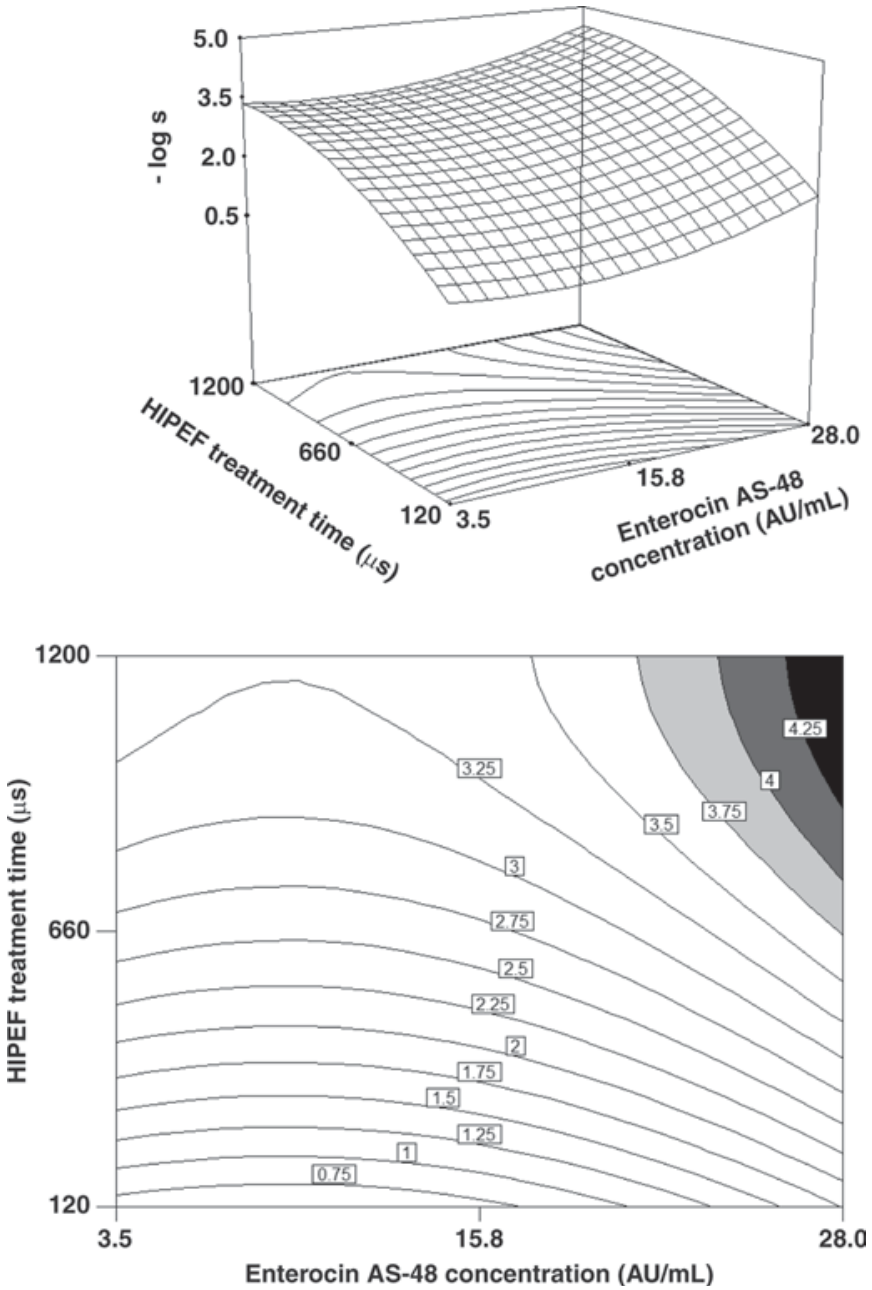

Figure 1. Effect of increasing enterocin AS- 48 concentration (arbitrary units $/ \mathrm{mL}$ ) and high-intensity pulsed-electric field (HIPEF) treatment time on the microbial inactivation of Staphylococcus aureus in milk at its natural $\mathrm{pH}$ (HIPEF set up at $35 \mathrm{kV} / \mathrm{cm}, 6 \mu$ s of pulse width, and $75 \mathrm{~Hz}$ at bipolar mode).

and a nonsignificant lack of fit (Table 4). The reduction in Staph. aureus population could be fitted by means of the following quadratic equation:

$$
\begin{gathered}
-\log s=-21.1-0.0635 \cdot e-0.00266 \cdot t+8.04 \cdot p \\
+0.00346 \cdot e^{2}-2.22 \cdot 10^{-6} \cdot t^{2}-0.722 \cdot p^{2}+0.00119 \cdot t \cdot p, \quad[2]
\end{gathered}
$$

where $-\log s$ represents the number of $\log$ reductions, $e$ the AS-48 concentration $(\mathrm{AU} / \mathrm{mL}), t$ the treatment time $(\mu \mathrm{s})$, and $p$ the $\mathrm{pH}$ of milk. On the basis of this model, maximum destruction of Staph. aureus, of 4.5 $\log$ reductions, was achieved when $28 \mathrm{AU} / \mathrm{mL}$ of AS- 48 was added to milk at its natural $\mathrm{pH}$, which was then treated with HIPEF for 1,200 $\mu$ s (Figure 1). This level of destruction represented $1.3 \log$ reductions more than the cell death achieved by summing the inactivation obtained by each of the treatments applied separately. However, counts of Staph. aureus in the samples at $\mathrm{pH}$ 5.0 treated simultaneously with AS-48 and HIPEF were no different, in the best of cases than those obtained when using only HIPEF. The number of viable microorganisms in samples at $\mathrm{pH} 6.8$ with $28 \mathrm{AU} / \mathrm{mL}$ of AS-48 processed with HIPEF for $1,200 \mu \mathrm{s}$ remained constant during storage at $4^{\circ} \mathrm{C}$ for $48 \mathrm{~h}$, whereas a growth in the population up to the initial inoculated level was observed in the same samples after $48 \mathrm{~h}$ if storage was held at $22^{\circ} \mathrm{C}$.

\section{Effect of HIPEF in Combination with Added Enterocin AS-48 and Nisin or Lysozyme}

The inactivation achieved by combining nisin and AS-48 (28 AU/mL) in milk samples, which were then treated with HIPEF, is shown in Table 2. As can be seen in the ANOVA (Table 5), the model fitted the response variable with a determination coefficient $\left(\mathrm{R}^{2}\right)$ of 0.97 and a nonsignificant lack of fit. The regression coefficients are shown in Table 4. The number of log reductions $(-\log s)$ was fitted by means of the following polynomial equation:

$$
\begin{gathered}
-\log s=1.50-0.0658 \cdot n+0.0103 \cdot t \\
+0.00525 \cdot n^{2}-6.53 \cdot 10^{-6} \cdot t^{2}
\end{gathered}
$$

where $n$ is the nisin concentration $(\mathrm{IU} / \mathrm{mL}$ ) and $t$ is the HIPEF treatment time $(\mu \mathrm{s})$. The greatest effect achieved by combined treatment with nisin, AS-48, and HIPEF was a log reduction of 6.3 , which was obtained by combining $28 \mathrm{AU} / \mathrm{mL}$ of AS- $48,20 \mathrm{IU} / \mathrm{mL}$ of nisin, and HIPEF treatment for $800 \mu \mathrm{s}$ at $\mathrm{pH}$ 6.8. This level of inactivation is, on the one hand, almost double that obtained when summing the maximum levels achieved by each of the treatments if applied separately and, on the other, shows an increase of approximately $1 \mathrm{log}$ reduction compared with the level achieved by summing the maximum effect obtained by HIPEF and that achieved with the combined addition of AS- 48 and nisin. Furthermore, after $48 \mathrm{~h}$ of storage at $4^{\circ} \mathrm{C}$, viable microorganism counts in the samples treated with the previous combination of variables remained stable, although a growth in the Staph. aureus population was observed in the same samples stored at a temperature of $22^{\circ} \mathrm{C}$.

The addition of lysozyme to samples with AS-48 previously treated with HIPEF neither enhanced nor modified the level of inactivation achieved compared with the same samples treated without lysozyme. 
Table 5. Analysis of variance and significant regression coefficients for the response surface quadratic model of microbial inactivation of Staphylococcus aureus in milk by combining the addition of enterocin AS-48 (28 $\mathrm{AU} / \mathrm{mL}$ ) and nisin with high-intensity pulsed-electric field (HIPEF; $35 \mathrm{kV} / \mathrm{cm}, 6 \mu$ s of pulse width, and $75 \mathrm{~Hz}$ of frequency at bipolar mode)

\begin{tabular}{lcrcc}
\hline Source $^{1}$ & Mean square & F-value & Probability $>$ F & Regression coefficients $^{2}$ \\
\hline Model & 4.06 & 71.77 & $<0.0001^{3}$ & $1.50 \pm 0.26$ \\
Intercept & 1.07 & 18.93 & $0.0024^{3}$ & $-0.0658 \pm 0.0231$ \\
$n$ & 4.96 & 87.72 & $<0.0001^{3}$ & $0.0103 \pm 0.0005$ \\
$t$ & 0.62 & 10.96 & $0.0107^{3}$ & $0.00525 \pm 0.00158$ \\
$n^{2}$ & 10.01 & 176.83 & $<0.0001^{3}$ & $-6.53 \times 10^{-6} \pm 4.91 \times 10^{-7}$ \\
$t^{2}$ & 0.079 & 2.28 & 0.2218 & \\
Lack of fit & 0.035 & & & \\
Pure error & 0.24 & & & \\
SD & 4.69 & & & \\
Mean & 5.08 & & \\
CV & 0.97 & & \\
$\mathrm{R}^{2}$ & 0.96 & & \\
Adjusted $\mathrm{R}^{2}$ & & & \\
${ }^{1} n=$ nisin concentration (IU/mL); $t=$ HIPEF treatment time $(\mu \mathrm{s})$. & \\
${ }^{2}$ Mean \pm standard deviation. & \\
${ }^{3}$ Significant at $95 \%$ confidence interval.
\end{tabular}

\section{Effect of the Sequence of Application of HIPEF and Bacteriocins AS-48 or Nisin, or Both}

The addition of AS-48 to samples treated previously by HIPEF did not improve the lethality achieved by processing the samples with HIPEF alone or by processing them with HIPEF after the addition of AS-48. Likewise, after storage for 24 or $48 \mathrm{~h}$ at $4^{\circ}$ or $22^{\circ} \mathrm{C}$, no differences in the counts were observed among the samples treated with HIPEF before or after the addition of AS-48. Similarly, no differences were observed in the number of log reductions in samples with AS-48 $(28 \mathrm{AU} / \mathrm{mL})$ and nisin $(20 \mathrm{IU} / \mathrm{mL})$, whether treated previously with HIPEF or not, or even in the survivor counts during storage.

\section{DISCUSSION}

The addition to milk of each of the antimicrobials AS48 , nisin, or lysozyme on their own did not lead to any reduction in the Staph. aureus population within the range of concentrations and $\mathrm{pH}$ levels tested. Among the most important features of $\mathrm{AS}-48$ is its stability under different $\mathrm{pH}$ and temperature conditions, as well as its wide antimicrobial spectrum (Diaz et al., 2003). In the particular case of Staph. aureus, Muñoz et al. (2007) found that the minimum dosage to succeed in inhibiting growth of the CECT 976 strain in milk was $50 \mu \mathrm{g} / \mathrm{mL}$. That result explains the sublethal or nonexistent effect of the concentration of AS-48 used in this study $(8 \mu \mathrm{g} / \mathrm{mL}$, equivalent to $28 \mathrm{AU} / \mathrm{mL})$ against the target strain of Staph. aureus. Similarly, other authors determined that the minimum lethal concentrations of nisin and lysozyme are higher than the maximums used in this study. Sobrino-López and Martín-Belloso (2006) observed that the concentration of nisin necessary to achieve a lethal effect on Staph. aureus in milk was $20 \mathrm{IU} / \mathrm{mL}$, and Chun and Hancock (2000) detected a reduction in the population of the microorganism above $12,000 \mathrm{IU} / \mathrm{mL}$ of lysozyme. In the case of this latter antimicrobial, the modifications in the peptidoglycans of the Staph. aureus cell membrane, consisting of O-acetylation, may also explain the low activity of lysozyme against this microorganism (Clarke and Dupont, 1992).

Although the activity of each of the antimicrobials separately was not sufficient to inhibit the growth of Staph. aureus in the ranges of concentrations used, the combination of AS-48 $(28 \mathrm{AU} / \mathrm{mL})$ and nisin $(20 \mathrm{IU} / \mathrm{mL})$ did manage to reduce the population by $1.8 \log$ cycles after an hour of exposure and almost up to detection level when the milk samples, at their natural $\mathrm{pH}$, were exposed for $24 \mathrm{~h}$ at $22^{\circ} \mathrm{C}$. These results suggest that the 2 peptides together act synergistically to destroy Staph. aureus even when their individual concentrations are at sublethal levels. However, the joint, simultaneous activity of the 2 peptides seems to be intrinsically dependent on $\mathrm{pH}$, temperature, and exposure time to the 2 substances. Contrary to what might be expected, higher acidic levels in the milk reduced the combined activity of AS-48 and nisin, when their activity separately is higher precisely at low pH levels (Ananou et al., 2004). Abriouel et al. (2001) proposed that certain changes in the oligomerization of the AS-48 molecule, together with a change in the surface electrical charge of the target bacteria, could alter the activity of the bacteriocin at low $\mathrm{pH}$ conditions. This fact could probably explain the loss of synergy between the 2 molecules when the milk 
$\mathrm{pH}$ was 5.0 within the range of concentrations studied. Until now, no other study has highlighted the synergistic effect of the simultaneous addition of enterocin AS-48 and nisin to milk, although it has been observed that the bactericide effect of AS-48 increases when it is combined with organic acids, such as benzoic, sorbic, and lactic (Ananou et al., 2007), or chelating agents, such as sodium tripolyphosphate and EDTA (Ananou et al., 2005a).

Temperature and, above all, exposure time seem to indicate the level of involvement of each molecule in the inhibiting effect. On the one hand, it was observed that nisin acts immediately or in a very short period of time (Hyde et al., 2006), thus the reduction observed during the first hour is directed and controlled principally by this molecule. On the other hand, the action of AS- 48 is mainly responsible for the inhibition achieved after 24 or $48 \mathrm{~h}$ of storage. However, temperature is the factor that acts as an accelerator or decelerator of the activity during that period of time. Thus, a temperature of $22^{\circ} \mathrm{C}$ during storage accelerated and intensified the joint activity of the peptides during the first $24 \mathrm{~h}$, although that activity stopped during the following $24 \mathrm{~h}$, with a consequent regrowth in the population of Staph. aureus. On the contrary, a temperature of $4^{\circ} \mathrm{C}$ first slowed the inhibiting effect of the bacteriocins, but prolonged the decrease in the population up to $48 \mathrm{~h}$ and, second, may have acted as a third treatment in itself with a bacteriostatic effect, given the thermophilic nature of the bacteria under study.

As can be seen in Figure 1, the number of log reductions achieved by HIPEF treatment of milk, at natural $\mathrm{pH}$ and with enterocin AS-48, increased as treatment time and AS-48 concentration reached their maximum values. The combination of HIPEF and AS-48 in inactivating Staph. aureus was synergistic. The loss of cell viability as a result of HIPEF treatment is basically due to cell damage that leads to permanent or transitory permeabilization of the membrane (Garcia et al., 2007). Thus, enterocin AS-48 may act with the induced electrical field in 3 possible ways: i) by maintaining and preventing the resealing of transient pores, ii) by enabling the formation of pores and disruption of the cell membrane by previous sensitization, and iii) by aiding in the extension of the permeabilization of the cell membrane above the critical level of cell viability. However, this pattern was not observed when milk $\mathrm{pH}$ was 5.0. Although the involvement of $\mathrm{pH}$ in the overall effectiveness of the treatment is not clear, a different conformation of the AS-48 molecule, together with a change in the sensitivity of the cell under these conditions (Abriouel et al., 2001; Ananou et al., 2007) or the ability of the bacteria to recover from possible sublethal damage inflicted by HIPEF treatment (Aronsson et al.,
2001), could explain the results observed at acidic $\mathrm{pH}$ values.

From a hurdle concept, the more preservation methods that are combined, the greater the inactivation that may be achieved. Although the addition of lysozyme to milk with added AS-48 and then treated with HIPEF did not improve the level of reduction of Staph. aureus compared with the same treatment without lysozyme, the addition of nisin to milk with added AS-48 (28 $\mathrm{AU} / \mathrm{mL}$ ), at natural $\mathrm{pH}$ and then treated with HIPEF, did noticeably reduce the population of Staph. aureus. In this case, the number of log reductions depended on the concentration of nisin and the treatment time. Specifically, maximum destruction was observed for a HIPEF treatment time of $800 \mu$ s (Figure 2), and both lower and higher times were less effective in reducing the population. Similar behavior was described by Sobrino-López and Martín-Belloso (2006) when milk inoculated with Staph. aureus and with added nisin was treated with HIPEF. In this case, an increase in the treatment time decreased the effectiveness of the combined treatment. In spite of the high level of initial destruction, the microbial population in the samples treated remained constant during storage at $4^{\circ} \mathrm{C}$ up to $48 \mathrm{~h}$. This result contrasts with the behavior observed at the same temperature when only the 2 bacteriocins were added, when decrease in the population was gradual (Table 3).

With regard to the sequence of application, the addition of AS-48, or of AS-48 combined with nisin, to milk previously treated with HIPEF did not enhance the lethal effect of the treatment as compared with when HIPEF was applied after the addition of the bacteriocins. Likewise, no increase was observed in the counts of viable microorganisms when the samples were stored at $4^{\circ}$ and at $22^{\circ} \mathrm{C}$. This loss of effectiveness, contrary to what was to be expected (i.e., an increase in the lethality of Staph. aureus after the addition of the bacteriocins caused by the prior HIPEF damage to the cell), could be due to 2 reasons. Different authors have observed that the electropermeabilization of the cell membrane may be reversible depending on the degree of structural damage caused and its recovery occurs immediately after the ending of the treatment (Tsong, 1990; García et al., 2007). Thus, the sensitivity induced in the membrane would be lost before the bacteriocins could act. The second reason is that the changes caused in the membrane by the action of the electrical field (Calderon-Miranda et al., 1999) may prevent or hinder the adhesion of the peptides, which would trigger an apparent increase in the resistance of the microorganism.

In conclusion, the treatment of milk with added AS-48 or nisin, or both, at sublethal doses with HIPEF acted 


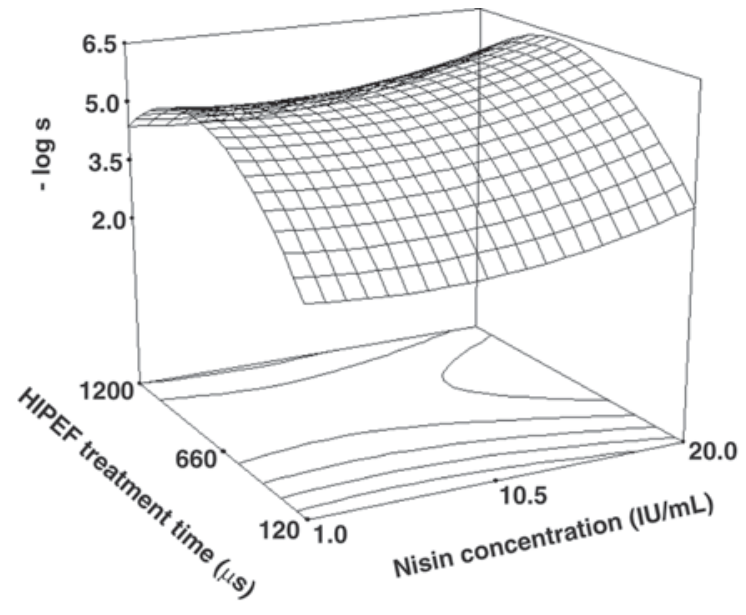

\section{ACKNOWLEDGMENTS}

This work was supported by the Generalitat de Catalunya (research group 2005SGR-00058) and the University of Lleida (Spain). We also acknowledge the Research Programme of the University of Jaén (Spain), from which Pilar Martínez Viedma received a fellowship, and the Research Plan of the Junta de Andalucía (research group AGR230). We also thank Terence W. Roberts for revising the manuscript.

\section{REFERENCES}

Abriouel, H., E. Valdivia, A. Gálvez, and M. Maqueda. 2001. Influence of physico-chemical factors on the oligomerization and biological activity of bacteriocin AS-48. Curr. Microbiol. 42:89-95.

Abriouel, H., E. Valdivia, M. Martínez-Bueno, M. Maqueda, and A. Gálvez. 2003. A simple method for semi-preparativescale production and recovery of enterocin AS-48 derived from Enterococcus faecalis subsp. liquefaciens A-48-32. J. Microbiol. Methods 55:599-605.

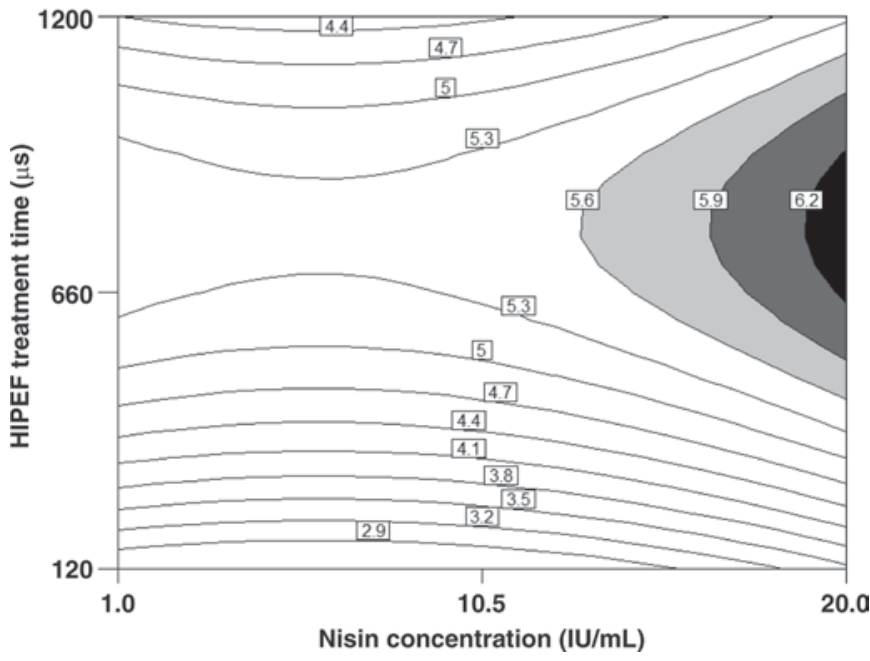

Ananou, S., A. Gálvez, M. Martínez-Bueno, M. Maqueda, and E. Valdivia. 2005a. Synergistic effect of enterocin AS-48 in combination with outer membrane permeabilizing treatments against Escherichia coli O157:H7. J. Appl. Microbiol. 99:13641372 .

Ananou, S., M. Maqueda, M. Martínez-Bueno, A. Gálvez, and E. Valdivia. 2005b. Control of Staphylococcus aureus in sausages by enterocin AS-48. Meat Sci. 71:549-556.

Ananou, S., M. Maqueda, M. Martínez-Bueno, A. Gálvez, and E. Valdivia. 2007. Bactericidal synergism through enterocin AS-48 and chemical preseratives against Staphylococcus aureus. Lett. Appl. Microbiol. 45:19-23.

Ananou, S., E. Valdivia, M. Martínez-Bueno, A. Gálvez, and M. Maqueda. 2004. Effect of combined physico-chemical preservatives on enterocin AS-48 activity against the enterotoxigenic Staphylococcus aureus CECT 976 strain. J. Appl. Microbiol. 97:48-56.

Aronsson, K., M. Lindgren, B. R. Johansson, and U. Ronner. 2001 Inactivation of microorganisms using pulsed-electric fields: The influence of process parameters on Escherichia coli, Listeria innocua, Leuconostoc mesenteroides and Saccharomyces cerevisiae. Innov. Food Sci. Emerg. Technol. 2:41-54.

Figure 2. Microbial inactivation of Staphylococcus aureus in milk by combining nisin (1 to $20 \mathrm{IU} / \mathrm{mL}$ ) and enterocin AS-48 (28 arbitrary units $/ \mathrm{mL}$ ) addition before applying high-intensity pulsed-electric field (HIPEF) treatment $(35 \mathrm{kV} / \mathrm{cm}, 6 \mu \mathrm{s}$ of pulse width, and $75 \mathrm{~Hz}$ of frequency at bipolar mode).

in a synergistic way to destroy Staph. aureus. However, the possible application of the combined treatment should be studied on acidic dairy products, due to its loss of effectiveness under these $\mathrm{pH}$ conditions. It is also necessary to study in greater depth the joint mode of action of the 2 bacteriocins combined with HIPEF and to evaluate the effect of the application of HIPEF on the activity of the bacteriocins. However, the degree of destruction achieved with the combination of the above treatments, that is, the addition of AS-48 or nisin, or both, together with the application of HIPEF, and the prolongation of the inhibiting or bactericide effect during later storage could be of great interest for the preservation of both milk and other dairy products.

Bendicho, S., G. V. Barbosa-Cánovas, and O. Martín. 2002. Milk processing by high intensity pulsed electric fields. Trends Food Sci. Technol. 13:195-204.

Calderon-Miranda, M. L., G. V. Barbosa-Cánovas, and B. G. Swanson. 1999. Transmission electron microscopy of Listeria innocua treated by pulsed electric fields and nisin in skimmed milk. Int. J. Food Microbiol. 51:31-38.

Chun, W., and R. E. W. Hancock. 2000. Action of lysozyme and nisin mixtures against lactic acid bacteria. Int. J. Food Microbiol. 60:25-32.

Clarke, A., and C. Dupont. 1992. O-acetylated peptidoglycan: Its occurrence, pathobiological significance, and biosynthesis. Can. J. Microbiol. 38:85-91.

Diaz, M., E. Valdivia, M. Martínez-Bueno, M. Fernández, A. S. Soler-González, H. Ramírez-Rodrigo, and M. Maqueda. 2003. Characterization of a new operon, as- $48 \mathrm{EFGH}$, from the $a s-48$ gene cluster involved in immunity to enterocin AS-48. Appl. Environ. Microbiol. 69:1229-1236.

EEC. 1983. EEC Commission Directive 83/463/EEC introducing temporary measures for the designation of certain ingredients in the labelling of foodstuffs for sale to the ultimate consumer. Off. J. L 255:15/09/83:1.

FDA. 1988. Nisin preparation: Affirmation of GRAS status as a direct human food ingredient. Fed. Reg. 53:11247. 
Gálvez, A., H. Abriouel, R. Lucas López, and N. Ben Omar. 2007. Bacteriocin-based strategies for food biopreservation. Int. J. Food Microbiol. 120:51-70.

Gálvez, A., M. Maqueda, E. Valdivia, A. Quesada, and E. Montoya. 1986. Characterization and partial purification of a broad spectrum antibiotic AS-48 produced by Streptococcus faecalis. Can. J. Microbiol. 32:765-771.

García, D., N. Gómez, P. Mañas, J. Raso, and R. Pagán. 2007. Pulsed electric fields cause bacterial envelopes permeabilization depending on the treatment intensity, the treatment medium $\mathrm{pH}$ and the microorganism investigated. Int. J. Food Microbiol. 113:219227.

Grande, M. J., R. Lucas, H. Abriouel, E. Valdivia, N. Ben Omar, M. Maqueda, M. Martínez-Bueno, M. Martínez-Cañamero, E. Valdivia, and A. Gálvez. 2005. Control of Alicyclobacillus acidoterrestris in fruit juices by enterocin AS-48. Int. J. Food Microbiol. 104:289-297.

Hyde, A. J., J. Parisot, A. McNichol, and B. B. Bonev. 2006. Nisininduced changes in Bacillus morphology suggest a paradigm of antibiotic action. Proc. Natl. Acad. Sci. USA 103:19896-19901.

Jung, D. S., F. W. Bodyfelt, and M. A. Daeschel. 1992. Influence of fat and emulsifiers on the efficacy of nisin in inhibiting Listeria monocytogenes in fluid milk. J. Dairy Sci. 75:387-393.

MacGregor, S. J., O. Farish, R. Fouracre, N. J. Rowan, and J. G. Anderson. 2000. Inactivation of pathogenic and spoilage microorganisms in a test liquid using pulsed electric fields. IEEE Trans. Plasma Sci. 28:144-149.

Martínez-Bueno, M., A. Galvez, E. Valdivia, and M. Maqueda. 1990. A transferable plasmid associated with AS-48 production in Enterococcus faecalis. J. Bacteriol. 172:2817-2818.

Masschalck, B., and C. Michiels. 2003. Antimicrobial properties of lysozyme in relation to foodborne vegetative bacteria. Crit. Rev. Microbiol. 29:191-214.
Molinos, A. C., H. Abriouel, N. Ben Omar, E. Valdivia, R. Lucas, M. Maqueda, M. Martínez-Cañamero, and A. Gálvez. 2005. Effect of immersion solutions containing enterocin AS-48 on Listeria monocytogenes in vegetable foods. Appl. Environ. Microbiol. $71: 7781-7787$

Muñoz, A., S. Ananou, A. Gálvez, M. Martínez-Bueno, A. Rodríguez, M. Maqueda, and E. Valdivia. 2007. Inhibition of Staphylococcus aureus in dairy products by enterocin AS-48 produced in situ and ex situ: Bactericidal synergism with heat. Int. Dairy J. 17:760769 .

Myers, R. H., and D. C. Montgomery. 2002. Response Surface Methodology: Process and Product Optimization Using Designed Experiments. John Wiley \& Sons, New York, NY.

Rodríguez, E., J. L. Arques, P. Gaya, J. Tomillo, M. Nunez, and M. Medina. 2000. Behaviour of Staphylococcus aureus in semi-hard cheese made from raw milk with nisin-producing starter cultures. Milchwissenschaft 55:633-635.

Sobrino-López, A., and O. Martín-Belloso. 2006. Enhancing inactivation of Staphylococcus aureus in skim milk by combining high-intensity pulsed electric fields and nisin. J. Food Prot. 69:345-353.

Sobrino-López, A., R. Raybaudi-Massilia, and O. Martín-Belloso. 2006. High intensity pulsed electric field variables affecting Staphylococcus aureus inoculated in milk. J. Dairy Sci. 89:3739-3748.

Tsong, T. Y. 1990. On electroporation of cell membranes and some related phenomena. Bioelectrochem. Bioenerg. 24:271-295.

Wu, Y., G. S. Mittal, and M. W. Griffiths. 2005. Effect of pulsed electric field on the inactivation of microorganisms in grape juices with and without antimicrobials. Biosystems Eng. 90:1-7. 